Vladimir Matović ${ }^{1}$

SCIENTIFIC REVIEW ARTICLE

Singidunum University, Faculty of Business in Belgrade doi:10.5937/ekonomika1504141M

Miroslav Knežević2

Singidunum University, Faculty of Tourism and

Received: September 17, 2015

Hospitality Management

Accepted: October 20, 2015

Tatjana Papić Brankov ${ }^{3}$

Institute of Agricultural Economics

\title{
THE NECESSITY TO ADJUST TRADITIONAL INTEGRATED MARKETING COMMUNICATIONS TOOLS AND TECHNIQUES TO NEW GLOBAL TRENDS
}

\begin{abstract}
The concept of integrated marketing communications is an essential part of the overall strategic planning of business entities and its significance for proper positioning, gaining and maintaining competitive advantage, makes it one of the most important concepts. These are a set of strategic decisions that can not be made separately but must take into account the interdependence of key elements of the marketing mix and the criteria for the selection of tools and techniques of mass and direct communication in order to achieve a synergy effect and result in a score greater than the sum of individual factors. Although necessary, the traditional concept of integrated marketing communications materialized in the tools and techniques of mass and direct communication due to changed business conditions slowly loses out on both efficiency and effectiveness. The emergence of new concepts is the result of the functioning of global trends and aspirations of economic entities to achieve maintain or improve their competitive position and their position in the minds of consumers while dealing with changing business conditions.
\end{abstract}

Key words: marketing, IMC, market, global trends

JEL classification: M20, M31, M37

\section{НЕОПХОДНОСТ ПРИЛАГОЪАВАЊА ТРАДИЦИОНАЛНИХ СРЕДСТВА И ТЕХНИКА ИНТЕГРИСАНИХ МАРКЕТИНШКИХ КОМУНИКАЦИЈА НОВИМ ГЛОБАЛНИМ ТРЕНДОВИМА}

\begin{abstract}
Апстракт
Кониепт интегрисаних маркетиниких комуникаџија представља неизоставан део укупног стратегијског планирања привредних субјеката и по
\end{abstract}

\footnotetext{
${ }^{1}$ vmatovic@singidunum.ac.rs

2 mknezevic@singidunum.ac.rs

3 brankov.tatjana@gmail.com
} 
свом значају за правилно позиционирање, стицање и одржавање конкурентске предности, један је од најважнијих. Ради се о сету стратегијских одлука које се не могу доносити сепаратно већ се мора уважити однос међузависности кључних елемената маркетинг микса и критеријума за одабир средстава и техника масовног и директног комуницирања како би се постигао синергетски ефекат и добио резултат већи од простог збира појединачних чинилаца. И ако неопходан, традиционални концепт интегрисаних маркетиншких комуникација материјализован у средствима и техникама масовног и директног комуницирања, услед промењених услова пословања полако губи како на ефикасности тако и ефективности. Појава нових кониепата резултат је деловања глобалних трендова и тежюе привредних субјеката да и у промењеним условима пословања постигну, очувају или унапреде своју конкурентску позицију и позицију у свести потрошача.

Кључне речи: маркетинг, ИМК, тржиште, глобални трендови

\section{Introduction}

The paper aims to point out the necessity of the implementation of new marketing concepts for more efficient and effective communication of the company with its targeted market segment and / or the market as a whole. The basic hypothesis is contained in the assertion that traditional tools and techniques of mass and direct communication are losing their efficiency. Why traditional means IMC lose its effectiveness can be determined by analyzing and learning about global trends as well as their nature and character. In addition, previous mentioned may explain how the innovative concepts appeared and why they can perform better results. By presenting the concept of IMC, in the same time we explained the connection between the concepts of promotion and marketing mix in order to emphasize the interdependence of individual marketing strategies. The factors that must be taken into account in the selection of individual tools and techniques of mass and direct communication are also pointed out. After the presentation of the concept, in general, and the tools and techniques of mass and direct communication, one by one, we have listed examples of their deficiencies that occur in the application. The analysis of global trends describes the changes in the business environment which has affected the reduction of the efficiency and effectiveness of traditional means of IMC. Mentioned above, has led to new market-oriented responses of companies that have developed new approaches that are grown in the massiveness of application and become modern concepts of business. Green marketing, with permission, focused marketing, alliances and many other concepts are described and presented with any analysis of the global trend that has most contributed to their emergence and development. In the final section, the projection of expected trends in the following period and highlighted the implementation of the code of ethics and the human dimension of business through achieving market goals.

\section{What is the IMC concept and how does it function?}

The concept of Integrated Marketing Communications, created in the nineties of the last century (hereinafter IMC) consists of tools and techniques of mass and direct 
communication with the main goal to build, with the synergy of promotional instruments, an institutional image and help consumers in the purchase of goods and / or services. In addition to the foregoing, the concept of IMC serves as a powerful tool for the purpose of differentiation compared to the competition (Dobrijevic, 2011). Companies apply digital marketing content to support the implementation of multiple business objectives (Rakić et al., 2014).

Basically the concept of IMC does not act alone but must be related to the concept of the marketing mix that defines the individual strategies be it on price, product, distribution or promotion. The main problem occurs in the search for a compromise between the often or almost always conflicting strategic options. In fact, none of the strategies of the marketing mix can be defined independently and separately from the others, but only in conjunction with them. In particular, if we want to increase our market share, it is possible to achieve this by using price policy in two completely opposite ways. One line goes in the direction of reducing the price (price competition), while the other goes in the direction of differentiation by defining the price at a higher level than the average price on the market along with highlighting specific benefits that consumers highly appreciate and which differentiate us compared to the competition. The answer to the question of which option to choose can not be given without the analysis of the product as an element of the marketing mix. If it is positioned by the consumer as more valuable and more successful than the competition, ie. has the status of a brand, it is not advisable to choose the strategy of price competition because it will degrade the perception of the brand in the minds of consumers and reduce its "value". As a rule, branded products cost more than the average products from the correspondent group of the products, and the appropriate strategy in terms of prices would go in the direction of differentiation. When it comes to distribution as the third element of the marketing mix, in case of branded products that are, in accordance with the foregoing, more expensive than the average, depending on the nature and character of the product it is likely that in case of technical goods, cars and a higher level of product finishing we will choose, rather than an intensive one, a strategy of selective and in some cases exclusive distribution. Finally, the promotion strategy as the fourth element of the marketing mix depends on the previous three mentioned but also on a series of other factors that must be taken into account. Specifically, in addition to decisions regarding product, price and distribution, when we make decisions about how and what forms a set of tools and techniques which will enable us to transmit a message (hereinafter referred to as the promotional mix) we must also take into account:

1. The amount of financial resources at our disposal,

2. Activities of the competition and

3. The customer's need for information.

Depending to whom the information is addressed, tools and techniques that make the concept of IMC are divided into two main groups, namely, the tools and techniques of mass communication intended for the market as a whole:

1. Advertisement,

2. Propaganda,

3. Publicity,

4. Sales Promotion, 
5. Sponsorship and

6. The Internet.

In addition to these, there are tools and techniques of direct communication intended for individual consumers or a targeted market segment and they are:

1. Personal sales,

2. Direct marketing and

3. The Internet.

Which ever combination of tools and techniques of mass and direct communication is to be used, in order to avoid confusion of consumers, the message that is placed must be based on the same values. However this is not always easy to carry out, primarily due to the tendency of consumers to accept messages from the environment in their own way as well as the activities of competitors and their communication channels which can put our message in the wrong context.

\section{Why don't traditional IMC tools give enough results?}

Advertising and propaganda as paid forms of communication have a limited effect due to two main reasons. Firstly, communication channels are more than congested by the number and frequency of submissions of advertising and promotional messages since all competitors are trying to be visible and present. Second, because commercials and propaganda are paid forms of communication and due to the above mentioned facts are less trusted.

Publicity as an unpaid form of communication has an advantage over advertising and propaganda in terms of consumer confidence due to the fact that it is an unpaid form of communication but also has a serious deficiency which is reflected in its inability to influence the message that is sent and to create a positive attitude towards the company environment.

The main drawback of sales promotion is the insufficient focus of concept. By its nature and mode of implementation, sales promotion belongs to the group of tools and techniques of mass communication but does not answer the question whether it is primarily related to existing or new customers. By providing free amounts in relation to the standard packages or gift products that are the basic product for the same price awarded to existing - loyal customers and the new price sensitive customers which buy the product only on that occasion and only for the reasons stated. With the aforementioned facts the company is not able to reward loyal customers, which is one of the fundamental aspirations of the concept, but it sends a message that the customers had previously paid more than they needed to because the price with and without free amounts or gift products did not change.

Sponsorship as a form of mass communication aims to send a message about how companies share the same values with their customers be it sponsorship of a community concept (concert, exhibition, scientific and other events) or sponsorship of individuals (scientific and sporting achievements). In addition, it sends a message that the company is socially responsible, that a portion of the profits is allocated to what customers value and provides confidence that by the purchase of its products the customer also partially participates in these actions. The problem with sponsorship occurs primarily in response 
to the question of what and who to sponsor to avoid polarization of the audience due to divided sympathy, whether to sponsor in the case when there is a general, a major, gold and / or other categories because guided by the desire to support something that is essential for consumers we could also donate funds etc.

Finally, the Internet, which can serve as a means of mass and as a means of direct communication, although inevitable, inexpensive and fast, is not effective enough and generally its effectiveness is expressed more in online ordering than in promotion. In the case of treating the Internet as a means of direct communication, effectiveness is increased because individual companies contact - communicate with potential customers and achieve interaction.

Direct marketing in its initial form of direct addressing and establishing and maintaining contact with individual customers by mail, pamphlets, etc. has lost in importance and has become part of the broader context of a new trend called customized marketing which as its primary aspiration has individualization of offers and their adjustment to the individual and specific customer groups or individual buyer. Due to the foregoing it is referred to as the "Marketing 1 on 1"or targeted marketing.

Finally, personal sales as a means of direct communication that relies primarily on the human factor carries the risk of realization of business functions by the direct perpetrators, their dedication, motivation, expertise and tactfulness to customer relations. In addition, the possibility of buying on line has somewhat accustomed consumers to a more comfortable way of shopping where all the activities of the sales staff also has to be realized in order to get into communication with potential customers and it is often treated as an usurpation and an unnecessary derangement.

\section{What factors led to the need for implementation of innovative concepts?}

Modern business conditions are characterized by high volatility. The changes are frequent, unpredictable, occurring in irregular intervals and may differ as to the causes of origin and towards the consequences left behind. Changes that occur in certain segments of economic life and the environment lead to changes in economic entities, which results in the re impact on market developments.

However, compared to the previously reported tendencies based on the marketing approach, which materialize in the company's efforts to better meet the needs of consumers and be more successful than the competition, current business conditions require the implementation of a proactive approach and anticipation of future events, while the main goal of branding is to create needs and desire in the consumer instead of saturation. Both in the first and second case, the problem remains the same: How to communicate to the consumers what we do, how we realize it, what values guide us, what is the advantage of our offer compared to its main competitors and what benefit do, ultimately, consumers have?

The reasons for the emergence of the need for the implementation of innovative methods of communication with the target market segment and the market as a whole are numerous and begin with significant changes in terms of preferences and habits through to consumer culture. In determining the manner in which we approach the market, we 
give most of the attention to the size and growth of population, age structure and ethnic composition, education level, household models and regional characteristics, in one word demographic factors that enter into the domain of the external environment in which the company may not have an effect or it is possible in a very small extent. Changing of the age structure, coupled with slower population growth in developed market economies, is the most notable demographic shift. As a consequence, an "aging nation," is emerging ie. increase in participation of the group over 65 years old and the reduction of participation of teenagers, ie. the group of up to 20 years of age (Matovic et al., 2011). Half a century ago in France, there were 200 people aged over 100 years, while according to expert estimates, this figure in 2050 will amount to 150,000 . The total population will continue to grow, according to estimates, by 80 million people per year. With 2.8 billion people in 1955, the population had already reached the figure of 5.8 billion, while in 2025 the number of inhabitants will amount to 8 billion. The number of people older than 65 by 2025 from the current 390 will increase to 800 million. In accordance with the foregoing, the number of which will depend on the working-age population will reach $17.2 \%$. The number of those under age 20 is projected to fall from $40 \%$ to $32 \%$ in the period (Matovic et al., 2011). Average life expectancy in the world was just 45 years in 1955 , in 1965 it was 65 in 2025 it will amount to 73 years. Expert's estimates point to the fact that the rich will continue to get rich but that their life span, which is already longer than average, will continue to be extended. While the income gap between rich and poor countries is widening, the average life expectancy of the population of one part of the African continent is twice lower than in the developed world (Brit et al., 2000). Thus, the average life expectancy in the 30 countries that are considered to have the highest level of economic development is 75 years whereas in the African country of Malawi is 39.1 years in Sierra Leone to 37.9 years.

In accordance with the above, members of the marketing channel should follow all the changes in the demographic and socio-cultural environment. When it comes to the aging of consumers, marketing managers and sales managers should pay special attention to older consumers, their needs, habits and consumption structure. Dealers in retail stores should also have in mind the needs of the elderly and to allow them better accessibility of products on the shelves, wider aisles between shelves and the elimination of steps, the use of large print boards inside the store, the hiring of older sales people, training younger staff to be attentive to the elderly. It is desirable to promote orders through mail and by phone, home delivery and etc. Population aging creates the possibility of a change in the appearance of existing products to adapt to the physical limitations of the elderly members of the community. First of all, referring to the labels and instructions in larger format, packaging that is easy to open, equipment and transport that allow easier movement. In addition to trade, other areas of economic life such as tourism, health care and care will get a chance as well.

Global income inequality is increasing from year to year. The gap in income between rich and poor countries was 3: 1 in 1820, 35: 1 in 1950, 44: 1 in 1950 and 71:1 in 1992. The world's largest manufacturers are moving their companies towards the Far East in search of cheaper labor force with the aim of reducing production costs and increasing competition on the market (Brit et al., 2000). The structure of households has also suffered changes. Members of non-traditional households are mainly employed persons with the lack of free time, and in accordance with the preceding characterized 
determinant are presented in economic theory as - "time-oriented." Due to the aforementioned lack of time and due to less interest for household, for these consumers rational reasons play a minor role and marketing reasons have greater role, and they give the same priority to retailers with differentiated marketing against traders with generic offers and low prices.

The education level of the consumer has changed for the better. Educated consumers have more sophisticated needs when purchasing. They demand quality products and services, they examine the overall usability of the product, are less tolerant of poor service and are willing to buy private label where the difference in quality is insignificant compared to the price difference. Migrations lead to the disappearance of a number of markets and the emergence of new ones, and socio-cultural environment and the criteria and values directly affect shaping of the nature of consumers needs and their preferences. The above mentioned changes, along with the rising prices of health care have led to the development of new forms of distribution of health services in the form of specialized hospital departments and home visiting programs.

Ecology, today more than ever, is one of the most important factors when making a decision whether to buy something or not. When opting, price still has the most important role, followed by convenience of use, and then immediately after comes the effect on the environment. The Heinz Company uses recycled bottles for packaging of their products (ketchup) and thereby do not use tuna that is caught in nets that can be dangerous for dolphins (Grossman, 1992). Battery manufacturer Eveready, Ray-O-Vac and Panasonic for some time already have been producing mercury-free batteries (Hapoiney, 1990). A collection from the cosmetics company Estee Lauder is made from raw materials that are not tested on animals and the products are packaged in recycled packaging. However, the initiative comes from customers. A well known example is McDonald's which, after numerous customer complaints, has replaced its packaging made of styrofoam with paper (1994).

Hence, we should not confuse the term "green marketing" which is more than present in economic theory and it indicates any marketing activity, which creates a positive or reduces the negative impact of a product on the environment. For example, Alberto-Culver has quite inconspicuously left out chlorofluorocarbons which is harmful to the ozone layer from his VO5 hairspray. Later, he began advertising this product with the indication "ozone-friendly" (Stanton et al., 1994). An increased interest in health, a healthier lifestyle and condition is imperative for most demographic and economic groups of consumers. As a direct consequence of the foregoing, there has been an increase in the number of stores with sporting goods, fitness centers, macrobiotic shops and restaurants, and others. Consumer lifestyle is the way in which they lead their lives, including their activities, interests and opinions (Bennet, 1988). In the modern consumer it is noticeable that there is an increasing number of impulsive buying. For impulse buying the main characteristic is the lack of pre-prepared and determined plan.

The tendency of a growing market fragmentation in numerous micro-markets that differs by age, gender, ethnicity, education level, the style of life of the population, where each group has different needs and consumer characteristics. Micromarketing involves meeting the needs and desires of a special segment of consumers and in a specific way adjusts the marketing strategy in order to best meet the specific needs of this segment.

As the exact opposite of the previous one, globalization presents a comprehensive socio - economic and political process that goes beyond the framework of regional, 
national, racial, religious and block constraints, enabling a global character (Group of autors, 2001). A significant contribution to the process of globalization is provided by multinational companies with a wide network of branches. As a result of the aforementioned processes there is a need for global coordination of economic policies. This phenomenon is more recent and concerns primarily the co-ordination of economic policies of the 7 economically most developed countries of the West since it began in 1985, and was joined by Russia in 1998. Global marketing emerges from the process of globalization of markets or is linked to the market operations of global (world) corporations and is conceptually coherent with marketing practices that could be applied on a world scale in a recognizable way. The main motto of global marketing could be formulated as "be competitive globally, and compete locally". The global consumer is a person without prejudice, sophisticated and nuanced and layered needs, preferences clear and pronounced sensitivity to the manner and quality to satisfy their needs. In this way, a global consumer culture has been created, and can be seen as a movement in which the people of the world unite on the basis of common views on branded products and the use of individual services. Some products are fully associated with certain lifestyles that, following the introduction in one area and it remains accepted worldwide.

The process of internationalization is fully compatible with the previously mentioned phenomenon of globalization and refers primarily to the conduct of economic activity and business functions outside the country which the headquarters is located in. Companies usually decide to relocate part of their business outside the market in which they originated from and where they do the predominant part of their activity only after they believe that the additional investment to increase market share in the national economy will generate less profit from the investment of the same amount in neighboring countries. There are various forms of internationalization of businesses, from direct exports, relocation of part of the business beyond borders of the national economy (international or foreign origin companies), direct investments, franchising systems, etc.

Following a trend that causes changes in current ways of doing business and aims to achieve higher competitiveness is certainly reengineering. In addition to the termination of realization of certain business functions and their modifications and optimization, what also changes is the identity of the company and perception that customers have about it. Therefore, the tools and techniques by which the message is communicated to the market are changing. By applying reengineering, companies do not change the business area, they completely change the processes that follow in carrying out its business activities, or completely replace them (Milisavljeviæ et al., 2000). To implement business functions that have been found not to perform competitively almost always specialized companies are engaged, in one word, they use outsourcing. The company Electornic Data System (EDS), based in Dallas, founded by billionaire Ross Perot, was a pioneer in providing outsource services, especially those related to the processing of a database of a large number of clients. In the further stages of development, outsource application is further facilitated and accelerated in the application of information technology. However, the eternal problem of the imperative for achieving competitiveness opened a number of issues of which the most important is: how to achieve this? Benchmarking is a systematic and continuous process of measuring and comparing the business processes of an organization in relation to the business processes of leaders, anywhere in the world, 
in order to obtain information that will help the organization take action to improve its performance (Group of autors, 2001). The comparison of internal business activities with those of the market leaders gives extremely good results, which materialize in enhancing business performance, better acceptance by customers and more successful differentiation against competition.

In some cases, companies can estimate that they will jointly achieve a better result than is possible to make individually due to grueling competition. More developed forms of alliances in which relations of mutual dependence are accepted, involve the will of participants to modify their original ways of doing business in order to achieve mutual benefits. Such alliances are defined as strategic, because the participants are willing to replace their core business with synchronized operations aimed at the realization of common interests.

Many strategic alliances take the form of marketing alliances. They are divided into four basic categories:

- Product or Service Alliances, which arise when one company gives to another the license for the production of its products or the two companies enter the market with a completely new product. For example, Apple had teamed up with Digital Vax in order to design, manufacture and sell their product together.

- Promotional Alliances arise when a company agrees to perform the promotion of a product or service for another company. Burger King had teamed up with Disney in order to offer figures from cartoons Lion King and Pocahontes.

- Logistics Alliances arise when a company offers services of logistical support for products from other companies, and

- Cooperation on pricing occurs when one or more companies enter into special cooperation agreement about pricing. It is common for hotels and car rental companies that offer reciprocal discounts.

Alliances sometimes include links with competitors and / or customers. For example, when Motorola formed a partnership with Nextel-TV in order to build a new communications system that will compete with mobile phone systems, Motorola was the equipment supplier and competitor at the same time. The number of these complex alliances has increased considerably in a very short period of time. Perhaps the best example is Coca-Cola's relationship with McDonalds. This alliance is not only significant because McDonalds is Coca-Cola's largest customer, but because it is an alliance of their common goal and that is to win against Pepsi Co. Pepsi Co. a competitive manufacturer of soft drinks that threatens Coca-Cola, while its partners Pizza Hut, Tako Bell and KFC are direct competitors of McDonalds (Fortune, 1994). The sudden increase in the formation and scope of strategic alliances occurred during the 90s of XX century (Main, 1990). Only in the US, more than 20,000 alliances were formed between 1988 and 1992. The growth rate of formation of local strategic alliances was over $25 \%$. Return on investment of the alliances had increased by nearly $40 \%$ between 1988 and 1992, which is 50\% more than the average yield on investments of US corporations (Pekar, et al., 1994). German pharmaceutical giant Hoechst, for example, had entered into a strategic alliance with Copley Pharmaceuticals in order to successfully enter the US pharmaceutical market in expansion (Plishner, 1993). By the time they appear on the market, new pharmaceutical 
products may cost around \$ 200 million. By forming partnerships, the pharmaceutical giant Merck\&Co Inc., can help DuPont in the development and distribution of Du Pont's experimental active substances for medicines (Anfuso, 1994). Together, the two companies reduce the risk of launching pharmaceutical products. Merck invests in already developed experimental active substances for medicines, and DuPont has the benefit of Merck's extensive distribution network. When Blockbuster Entertainment Corp. wanted to expand beyond the video business, they used a series of strategic alliances. Blockbuster had first established a strong presence in the retail music industry by entered into an alliance with Virgin Retial Group. After this, Blockbuster had reorganized in order to adapt to the new common organization which was actively seeking profitable alliances (Zbar, 1993).

Alliances play a prominent role in the occupation of their competitive positions. "Alliances are created from the need to access new markets and to enhance the marketing, distribution and / or sales operations" (S. et al., 1992). Strategic alliances enable organizations to reduce duplication of resources and effort and at the same time strengthen their joint market power. In the same sense, Coca-Cola and Schweppes now jointly manage a factory for bottling of soft drinks. This allows them to invest capital in filling facilities and to apply the principles of total quality management of joint production. In this way, each company can economically and efficiently meet the market demand for soft drinks (Alliance, 1994).

All marketing channel members are focused on meeting the target market segments and therefore it is to be expected to gradually start to develop co-operation between the various market institutions that exist at different levels of marketing channels. Marketing of good relations that has emerged in the recent years of the twentieth century represents the identification, establishment, development and maintaining (and, if necessary, termination) of business relationships with customers and other stakeholders. The goal is the realization of profits in a way that will lead to the fulfillment of the objectives of all parties, which is achieved through a joint exchange and fulfillment of promises. The focus is more on retaining existing rather than on attracting new customers. The mentioned above should not be surprising, since according to research and numerous studies conducted in the US, the cost of attracting new customers is hundreds of times greater than the cost of retaining existing ones. Targeted or "target" marketing is the choice of target market segments and selection of the position that the company wants to occupy within the desired segment. The target market segment should be sufficiently large and capital intensive. What is particularly important is homogeneity within the segment and its diversity in preferences in relation to the rest of the market in order for the effects of targeted marketing to give maximum results. Along with the changes that the marketing of good relations and targeted marketing bring, the way of communication and addressing the company targeted market segment also changes. Sales and promotional activities cease to be aggressive and intrusive and increasingly give way to consultative concepts whereby firms present themselves as consumer agents. Today it is possible within 48 hours to receive a personal model of Nike sneakers whose pattern can be conceived by the buyer in any store in New York. Through information technology, the Timberland Company sends out its draft of the new collection which is sewed by the winner of the tender announced for that year. The company does not have any factory and all the products can be ordered on line by the customers. The term e-commerce 
is evolving over time and at this time we are unable to definitively and finally define the subject of analysis. At this point, e-commerce can be defined as the automation of commercial transactions using computers and communication technologies (Šapić, 2004). Through e-commerce companies are trying to take advantage of lower costs, to reduce errors and cycle times, have a high degree of adaptability of products or services and thus meet the wishes of customers.

As a result of the rapid development of modern information technology and its wider application in the sphere of trade, it becomes institutionally different than before. In fact, more often instead of Brick \& Mortar appear Klick \& Mortar traders without stores that do their transactions are with the support of information technology, in the form of orders and home delivery.

Modern forms of trade without facilities (electronic retailing) (Crnković, et al., 1998) are:

1. $\mathrm{TV} /$ radio programs:

- Free radio and TV channels - programs and parts of the program,

- Cable TV - programs and parts of the program,

- Commercial Information program ("Informecials") video - issues which can sometimes migrate from television to television,

- Cable TV and telephone: just for you, closed systems for ordering films or sports broadcasts,

- Interactive TV experiments (Videotext) a transformed TV with an interactive keyboard that allows the user to "return" information via the same channel,

- Electronic users.

2. Electronic kiosks:

- Kiosks for exploring (Browsers) - can contain video and music clips, recipes, tips etc.

- Kiosks for sale - tickets, cassettes, CDs and the like are usually sold.

3. Systems based on a focal computer and terminals:

- Sponsored systems - mainly from State or government agencies (eg. French TELETEL with a network of Munitel terminals that the post office gave to users instead of telephone directories),

- Commercial systems - usually more developed than several interested companies.

4. Systems based on personal computers:

- Public networks

- Closed networks

The congestion of communication channels, the number of received and sent messages, saturation of the target audience to whom the message should arrive and whose reaction should be gotten has led to a more creative approach to messaging and an offensive marketing strategy which has led to the emergence of Guerrilla marketing. The basis of this concept is to involve the rational part of the decision-making mechanisms of consumers while for the companies that meant that great ideas should be implemented with modest financial means. The literature often mentions the example of a small bookshop which was located right between two large and by all means more 
competitive bookshops of the same purposes. The ingenuity of the owner was that he wrote "main entrance" on his store and this lead to customers rationally thinking and entering his building instead of the two adjacent thinking that this is the right path to get to the books in the window. Hence the name "Guerrilla" because the concept means to fight, so to speak to ambush, with small budgets against large. Later, due to the efficiency of the concept, guerilla marketing began to be used by large companies as a more unconventional method of attracting audiences with the aim of initiating a public discussion and therefore the realization of publicity with the purpose of propaganda. In this regard, in order to be effective, the campaign of guerrilla marketing should be creative, bold, loud and rebellious, in one word spectacular. These actions come on suddenly and unannounced, and end in the same way. Their aim is to polarize the public and lead to discussions that should cause emotions and therefore stay longer in the minds of consumers than conventional advertisements. Despite the obvious advantages, there are also some disadvantages of the concept. First of all, what should be noted is a reduced ability to control and thus the lack in the concept is identical to the lack of control in publicity as a means of mass communication. We should keep in mind that the main purpose of the launch and initiating action is that the action can be initiated not only supporters of a product or company, but also their opponents. There are numerous examples of successful campaigns like the campaign Mini Cooper, which called on its supporters to submit their personal photos and thus get a chance to have their face on a billboard campaign, or for the Olympic Games in Atlanta in which Linford Christie participated with logo-lenses in the form puma eyes, or advertisements for the Zoo which was presented by label snakes enveloping the city bus and acted very suggestively on passers-by and many others.

\section{Conclusion}

Modern business conditions, due to the presence of current global trends, require the implementation of new and innovative approaches in the field of communications of companies with their targeted market segment and / or the market as a whole. Traditional tools and techniques of mass and direct communication, due to changed preferences and habits of consumers are losing out on efficiency and the effectiveness. The fact that most of the tools and techniques of communication are in their stages of maturity and that their use has increased by competing companies, directed towards seeking new and innovative models of communication to appropriated a greater effect on invested funds. In the near future it is realistic to expect their modification and assimilation to trends that have led to the emergence of new concepts which companies apply in communication with consumers. Even greater sophistication, a consultative relationship based on concern for health and environmental protection, the wider implementation of information technology along with other global trends will affect the further modification of the instruments of the communication mix. Emphasis will be on innovative concepts and a greater involvement of consumers and their activation in the communication process. In the near future we should expect that companies will communicate with the market in a manner to achieve full effectiveness and reach out to consumers with the exact aim which is construction of their value system, instead of supplying them with basic information. 
The confirmation of previous mentioned is presence of widespread application of research results "neuromarketing," which aims is to measure the psychological reactions of potential customers without their knowledge. Currently, companies measures heart rate, consecutive reactions of eye, blood pressure and total body reaction of potential consumers at some of the communication techniques in a controlled environment. The results of such research are fascinating how much and worrying. Measuring customer reaction to the busy streets of London indicated that the organism of potential consumers is in a state similar to professional fighter pilots. This indicates the necessity of application of ethical principles and to prevent possible abuses. Due to the foregoing, many successful companies today are reaching for "marketing by permission." In this regard the further development of the concept of communication, we should expect further development of tools and techniques of communication which are necessary to be combined with code of ethics.

\section{References}

Almassy, S., Baatz, E. B. (1992). 455 Electronics Execs Say Rugged Individualizm is Fading, Electronic Business 18, 38-39.

Anfuso, D. (1994). Helping Two Companies Form a Third, Personal Journal, 73(1), 63-64.

Brit, V., Eliot, L. (2000). Richer Lives Longer. The Guardian, 12.

Bennet, P. (1988). Dictionary of Marketing terms, American Marketing Association, Chicago, 106-107.

Capowski, G. (1994). Zen and the Art of an Alliance. Mangement Review, 83(12), 17-19

Crnković, J., Petković, G. (1998). Savremeni oblici elektronske trgovine. Nova Trgovina, 11-12/97, 1-2/98, 56.

Dobrijević, G. (2011). Poslovno komuniciranje i pregovaranje, Univerzitet Singidunum, Beograd, 63.

Friedman, L. (1994) Micromarketing Flourishes in Sporting Goods, Discount Store News 33(16), 84.

Grupa autora, (2001). Ekonomski rečnik, Ekonomski fakultet, Beograd, 193.

Grossman, L. (1992). Mall Restzless Itself as Black Schopping Center, Wall Street Journal, B1.

Hapoienu, S. L. (1990). The rise of micromarketing. Journal of Business Strategy, 11(6), 37-42

Main, J. (1990). Making Global Alliances Work. Fortune, 121-126.

Matović, V., Čavić, B. (2011). Menadžment prodaje, Univerzitet Singidunum, Beograd, 136-140.

Milisavljević, M., Todorović, J. (2000). Marketing stragegija, Ekonomski fakultet, Beograd, 25.

Pekar, P., Robert A. (1994). Making Alliances Work - Guidelines for Success. Long Range Planning, 27(4), 54-65. 
Plishner, E. S. (1993). Hoechst Repositions in US Pharmaceutical Market. Chemical Week, 153(14), 12.

Rakić, B.; Rakić, M. (2014). Digital Content_Marketing for Organisations as Buyers. Ekonomika, 60(1), 84-93

Quinlan, M. (1994). Things Go Better With Coke- Just Ask McDonald's. Fortune, 116.

Stanton, W., Etzel, M., Walker, B. (1994). Fundamentals of Marketing, $10^{\text {th }}$ ed. Mc Graw Hill Inc., New York, 636.

Šapić, D. (2004). E-commerce - poslovanje preko interneta, Daniel Print, Novi Sad, 11.

Zbar, J. (1993). Blockbuster Stars as Global Brand. Advertising Age, 64, 154. 